\title{
The diet of sledge dogs
}

\author{
BY R. J. F. TAYLOR \\ Department of Zoology, University of Cambridge, and the Falkland \\ Islands Dependencies Survey \\ A. N. WORDEN \\ Nutritional Research Unit, Huntingdon \\ AND C. E. WATERHOUSE \\ Research Laboratories, Bob Martin Limited, Southport
}

(Received 23 May 1957-Revised 22 February 1958)

The present activity in the Antarctic provided a stimulus for a study of the diet of sledge dogs. Observations made and results obtained in the Antarctic, together with cognate laboratory studies carried out in Britain, are here described. Experiments were made in Britain on dogs of various breeds, and in the Antarctic on huskies. The established sledging ration was found to be inadequate, so a product, pemmican, manufactured and supplied as blocks of $\mathrm{I} \mathrm{lb}$. to expeditions over the past 26 years was specially investigated. In consequence, a new diet of a completely different composition has been devised; large quantities of it were shipped to the Antarctic for the first time in the autumn of 1956 .

Britain maintains several permanent bases in the Antarctic and the largest of them is at Hope Bay, $63^{\circ} \mathrm{S}$., $57^{\circ} \mathrm{W}$., where one of us (R. J.F.'T.) spent the years of 1954 and 1955. At that time the complement at the base consisted of twelve men and about seventy-five dogs. The dogs, while at the base, received on alternate days $6-8 \mathrm{lb}$. of seal meat, most of which was muscle, fat and bone, but liver and heart were given occasionally. Most of the seal used as food was Lobodon carcinophagus and there is considerable evidence, backed by I2 years of practical experience, to show that such a diet of seal is almost, if not completely, adequate.

On journeys, however, a concentrated, dehydrated ration must be provided, since on a loaded sledge about $50 \%$ of the weight may be food for the dog team. The ration has consisted, for the last quarter century, of dog pemmican, usually in the form of I lb. blocks. Dog pemmican was first used by H. G. Watkins in 1930 (Watkins, 1932), and it has been manufactured and supplied for every expedition since then. It may be, therefore, that there has been variation in composition over that period. All the work here recorded, however, deals with a single sample received in bulk from the manufacturers and, therefore, presumably of a reasonably constant composition.

There have been complaints in the past that dog pemmican is inadequate as a sledging ration, but, until recently, there has been little factual evidence. It was known that the condition of the dogs deteriorated, with loss of weight and almost constant 
diarrhoea, and that the animals improved in health after a meal of seal meat. It was also known that after 6 weeks on the diet of dog pemmican sore gums and palatal ulcers might develop. This investigation confirmed those observations and revealed other signs, presumably of dietary origin. At the same time as the nutritional studies were made, the work output of the dogs was investigated. It was surprising to find that dogs with signs of severe disease could, nevertheless, continue to pull a heavy sledge.

A cognate study was undertaken in Britain to ascertain whether the diet of dog pemmican could be improved, and what were the effects of it as the only food on animals housed in metabolism cages. Fortunately, an adult husky dog was available on loan from the Falkland Islands Dependencies Scientific Bureau during the dog's limited stay in this country; we are most grateful to Sir Vivian Fuchs, Director of the Bureau, and to Mr C. E. Woodrow, M.R.C.V.S., for their help in the matter. Since that animal was the only husky available at the time and for a short period only, the study was extended to other breeds of dog which we had previously used for metabolic studies.

It was not, of course, possible in this country to imitate the environmental temperature of the Antarctic, or the amount of work done there by the dogs. The results, therefore, deal only with limited exercise in a temperate climate, but they appear to justify certain conclusions.

In the course of the work it seemed possible that metabolic disturbance was caused by the somewhat abnormal ratio of protein to carbohydrate in the pemmican diet. Further metabolism trials were, therefore, conducted with our normal diet for dogs (standard I, Table I) or with the dog pemmican and standard diets modified to readjust the ratio of protein to carbohydrate. From the results a new diet was devised, of which details are given. The new diet is now in regular use by the Falkland Islands Dependencies Survey, and at other centres, and was used by Sir Vivian Fuchs on his successful journey to the South Pole in $1957-8$.

\section{EXPERIMENTAL}

\section{Field work in the Antarctic}

Dogs. The original dogs of the Falklands Islands Dependencies Survey were brought from the Arctic. In 1944 and again in 1945 some forty dogs were introduced from Labrador (Adie, I953); in I954 there was a further introduction from Canada and Greenland (Falkland Islands Dependencies Survey, I956). The dogs are maintained at several isolated bases, but each year some are moved from base to base to meet changes in the general planning of the Survey. Most of the dog population at Hope Bay in 1954 and 1955 was in its third generation in the Antarctic. The mean weight of males at the base was $4 \mathrm{I} \mathrm{kg}$ and that of females $34 \mathrm{~kg}$. The ages of the dogs used for experiment varied from 2 to 7 years. A general description of the dogs and their maintenance is given by Taylor ( $1957 c$ ). Their work output was measured electrically for 2000 miles and the work done was calculated (Taylor, 1957a,b).

Tests at base. Tests were made at the base on dogs fed on pemmican and kept 
unworked. The dogs were chained on snow or housed in metabolism cages $3 \mathrm{ft} .6$ in. $\times 3 \mathrm{ft} .6$ in. $\times 3 \mathrm{ft}$. The first experiment lasted 38 days and its object was to find if a deficiency of thiamine or ascorbic acid might develop. The urine was collected periodically and analysed for bisulphite-binding substances by the method of Banerji \& Harris (1939) and for ascorbic acid by that of Harris \& Ray (1935). Finally, a loading test was carried out by injecting thiamine, and the urine was again examined.

Two other tests were concerned with gross changes. The faeces of individual dogs were collected daily and weighed. A representative portion of about $40 \mathrm{~g}$ was dried on a water-bath for ro $h$. The sample was again weighed before being placed in an air-tight tube. The samples were sent to Britain for analysis.

The dogs were weighed periodically on a spring balance, calibrated against a second balance, having a Board of Trade stamp, maintained in the base hut.

Experiments on journeys. Several sledge journeys of over 1000 miles have been recorded by parties using dogs fed on pemmican (Fuchs, I95 I; Lindsay, 1935; Mason, 1950). On all those journeys, however, the dogs occasionally had some form of fresh meat. The two longest recorded periods of continuous feeding on pemmican appear to be one of 70 days while travelling 650 miles in 1953 , and one of 59 days while travelling 670 miles in 1955 (Falkland Islands Dependencies Survey, I954, I956).

On most journeys, the diet was $\mathrm{I}$ lb. pemmican $/ 24 \mathrm{~h}$ but other diets were used. The actual daily rations, together with the times for which they were used, were: I lb. pemmican for periods of up to 39 days; $\mathrm{I} \frac{1}{4} \mathrm{lb}$. pemmican for periods of 50 days; I lb. of a ration similar to pemmican in gross composition, except that whale meat replaced the beef meal in pemmican, for 16 days; $\mathrm{I}$ lb. of a diet, half of pemmican and half of seal blubber, containing $65 \%$ fat, given for 7 days.

On each journey urine was collected periodically, 10\% by volume of glacial acetic acid was added and the urine was stored in metal screw-top containers completely filled for tests at the base. Samples of faeces were stored in air-tight tins. They became frozen and on reaching the base were sent to Britain as already described.

All the temperatures recorded at base and on journeys are dry-bulb, air temperatures.

\section{Laboratory work in Britain}

Dog pemmican. The basis of the pemmican used was beef, the approximate percentages by weight being beef meal 70 , beef fat 22 , yeast extract 4 and bone meal 4 . The beef meal, yeast and bone meal were mixed with the melted beef fat and the resulting mixture was poured into moulds each holding I $\mathrm{lb}$. When solid, the blocks were wrapped in parchment paper and packed in lots of forty-eight in hermetically sealed tins. Most of the dog pemmican made in 1953 was shipped to the Antarctic but some remained in Britain for analysis by the methods described by the Association of Official Agricultural Chemists ( 1955 ) for nitrogen, fat, crude fibre and ash. Calcium, phosphorus, magnesium, iron, cobalt and copper were determined as described by Godden (1937). Thiamine was measured by the thiochrome method (Harris \& Wang, I94I), nicotinic acid by the cyanogen- $p$-aminoacetophenone method (Kodicek, I940), and riboflavin fluorimetrically (Kodicek \& Wang, I949).

Dogs. Observations were made on three male dogs. Their management and the 
collection of samples have been previously described (Worden, Waterhouse \& Partington, 1952, I954, I955; Worden \& Waterhouse, I955; Worden, Waterhouse \& Pulman, 1956). The three dogs, two of which had been used in earlier studies, were Dusty, a 2-year-old husky, weighing $32-33 \mathrm{~kg}$, on loan, during its stay in England, from the Falkland Islands Dependencies Scientific Bureau and one of the consignment obtained from Greenland during 1954 to reinforce the existing numbers available in Grahamland; Pat, a 5-year-old black-and-white smooth-coated crossbred terrier, weighing 24-26 kg; Scottie, a 4-year-old Scottish terrier, weighing I $\mathrm{kg}$. An improved metabolism cage (Worden \& Waterhouse, 1956) was used.

Analysis of urine. Vitamin A was estimated as described by Worden, Bunyan, Davies \& Waterhouse (1955) after extraction by the method of Lawrie, Moore \& Rajagopal (194I). Thiamine was measured by the method of Jowett (1940), modified by Worden et al. (1952). To measure riboflavin, samples containing about ${ }_{5} \mu \mathrm{g}$ were acidified with $0.2 \mathrm{ml}$. conc. $\mathrm{HCl}(36 \%$, w/w) and the mixture was extracted with chloroform to remove extraneous soluble material. The aqueous layer was then treated by the procedure described by Kodicek \& Wang (1949). Ascorbic acid was measured by the method of Bessey (1938). The measurement of indican was by the following modification of Jaffe's test: to $5 \mathrm{ml}$. urine, $5 \mathrm{ml} .36 \%(\mathrm{w} / \mathrm{w}) \mathrm{HCl}$ and $\mathrm{I} 5 \mathrm{ml}$. $\mathrm{CHCl}_{3}$ were added and the mixture was shaken. Three drops of $\mathrm{I} \%(\mathrm{w} / \mathrm{v}) \mathrm{KClO}_{3}$ solution were added and the mixture was shaken for $5 \mathrm{~min}$. The $\mathrm{CHCl}_{3}$ layer was

Table I. Composition of the diets used in laboratory experiments in England, daily intakes and proportions of certain components

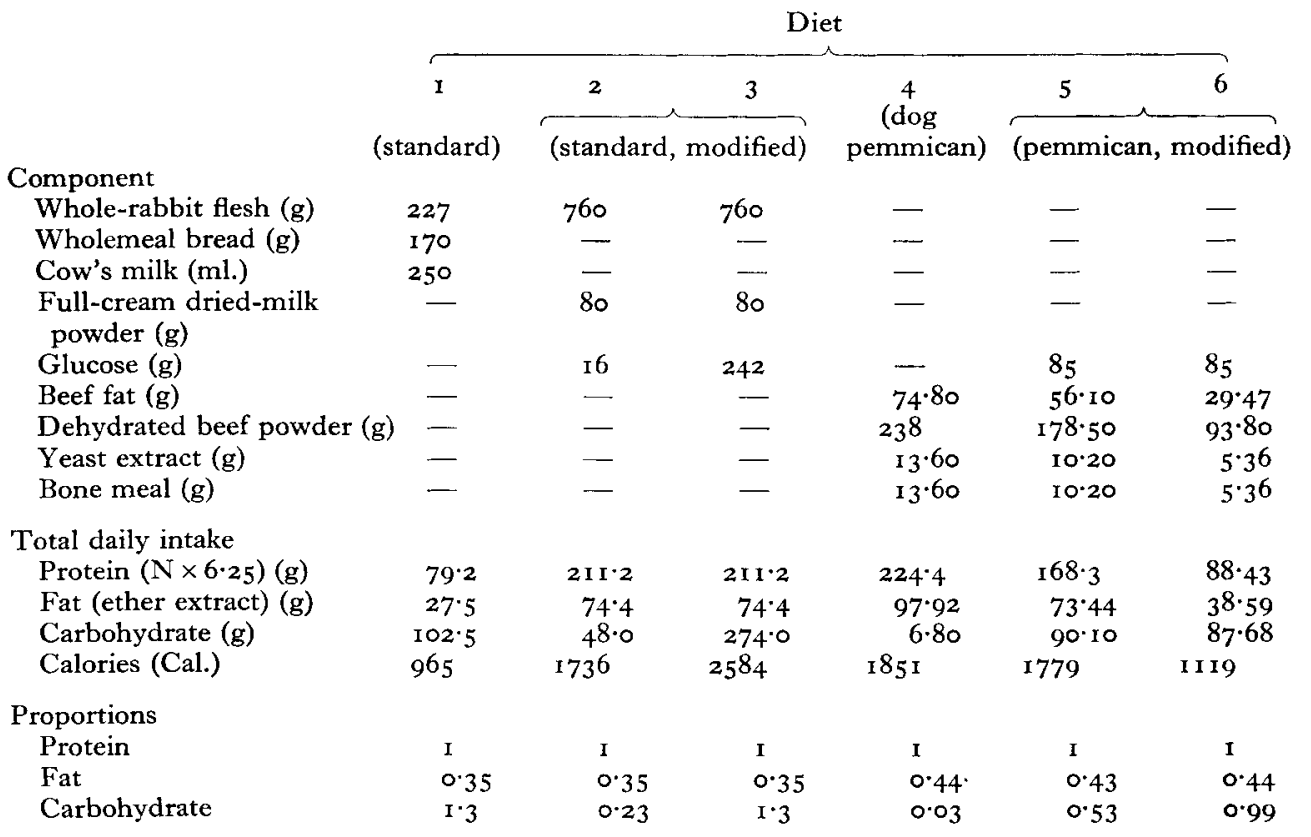

When on diet I the dog Scottie received three-quarters, and the dog Dusty twice, the quantities given above, which were those given to the dog Pat. 
separated, a further two drops of $\mathrm{I} \% \mathrm{KClO}_{3}$ and $\mathrm{io} \mathrm{ml} . \mathrm{CHCl}_{3}$ were added and the mixture was shaken for $5 \mathrm{~min}$. The mixed chloroform solution was washed with an equal volume of water. The chloroform solution was filtered through dry filter-paper and made up to $25 \mathrm{ml}$. The blue colour was compared against water as zero setting on a Biochem Absorptiometer (Hilger and Watts Ltd, London) with O.R. 2 red filter, and the result recorded as the galvanometer reading per $5 \mathrm{ml}$. sample.

Analysis of faeces. The fat content was estimated by extraction with ether (King, I95 I) and the protein by the micro-Kjeldahl technique.

Analysis of diets. Six experimental diets were used; details of the composition and of the proximate analysis are given in Table I. Diet I was the standard diet used in previous metabolism studies in these laboratories (Worden et al. 1952). Diet 4 was dog pemmican. Diets 2 and 3 were modifications of diet $I$ and diets 5 and 6 were similar modifications of diet 4 altering the proportions of protein, fat and carbohydrate.

Thiamine was extracted by the method of Kodicek \& Wang (1949), and determined as described for urine. For riboflavin the method of Kodicek \& Wang (1949) was used. Ascorbic acid was determined iodometrically by the method of Stevens as described by Winton \& Winton (1945).

\section{RESULTS}

\section{Field work in the Antarctic}

Composition of pemmican. The results of analysis (Table 2) show that dog pemmican was a dry and concentrated food consisting of about two-thirds protein and one-third fat with a little carbohydrate. It contained no appreciable amount of vitamin $A$ and little ascorbic acid.

Table 2. Proximate composition and mineral and vitamin

\begin{tabular}{|c|c|}
\hline \multicolumn{2}{|c|}{ content of dog pemmican } \\
\hline Proximate composition $(\mathrm{g} / \mathrm{1} 00$ & dry weight) \\
\hline $\begin{array}{l}\text { Protein }(\mathrm{N} \times 6.25) \\
\text { Fat (ether extract) } \\
\text { Fibre (crude) } \\
\text { Total ash } \\
\text { Carbohydrate (by difference) }\end{array}$ & $\begin{array}{r}66 \cdot 00 \\
28 \cdot 80 \\
0.08 \\
3 \cdot 10 \\
2 \cdot 02\end{array}$ \\
\hline \multicolumn{2}{|l|}{ Mineral content } \\
\hline $\begin{array}{l}\text { Calcium (\%) } \\
\text { Phosphorus }(\%) \\
\text { Magnesium (\%) } \\
\text { Iron (\%) } \\
\text { Cobalt (p.p.m.) } \\
\text { Copper (p.p.m.) }\end{array}$ & $\begin{array}{l}0.76 \\
0.52 \\
0.02 \\
0.05 \\
0.25 \\
1.40\end{array}$ \\
\hline \multicolumn{2}{|c|}{ Vitamin content $(\mathrm{mg} / \mathrm{I} \mathrm{lb}$. block) } \\
\hline $\begin{array}{l}\text { Vitamin A } \\
\text { Thiamine } \\
\text { Nicotinic acid } \\
\text { Riboflavin } \\
\text { Ascorbic acid }\end{array}$ & $\begin{array}{l}\text { Not detectable } \\
0.40 \\
17.80 \\
1 \cdot 46 \\
<\text { Io when made, } \\
<3 \text { a year later }\end{array}$ \\
\hline
\end{tabular}


Loss of weight. The weight changes of sledge dogs under various conditions are set out in Table 3. They show that dogs lost weight on the pemmican diet. The lower the temperature and the greater the work, the more marked was the loss of weight. Large dogs lost more weight than small ones. The mean daily loss in weight on a ration of I lb. pemmican/day varied from 0.3 to $0.9 \mathrm{lb}$.; the maximum loss recorded for an individual was $\mathrm{I}_{5} \mathrm{lb}$. in 9 days. The loss was least for three dogs doing no work.

Table 3. Weight changes of sledge dogs given 1 lb. or $\mathrm{I}_{4}^{\frac{1}{4}} \mathrm{lb}$. pemmican $/ 24 h$ in different working conditions

\begin{tabular}{|c|c|c|c|c|c|c|c|}
\hline \multirow[b]{2}{*}{$\begin{array}{l}\text { Date of } \\
\text { journey }\end{array}$} & \multirow[b]{2}{*}{$\begin{array}{l}\text { No. of } \\
\text { dogs }\end{array}$} & \multirow{2}{*}{$\begin{array}{l}\text { Duration } \\
\text { of journey } \\
\text { (days) }\end{array}$} & \multirow{2}{*}{\multicolumn{3}{|c|}{$\begin{array}{c}\text { Mean air } \\
\text { temperature } \\
\text { during } \\
\text { journey } \\
\left({ }^{\circ} \mathrm{F}\right)\end{array}$}} & \multirow{2}{*}{$\begin{array}{c}\text { Mean } \\
\text { work rate* } \\
\text { (Cal./24 h) }\end{array}$} & \multirow{2}{*}{$\begin{array}{c}\text { Mean } \\
\text { distance } \\
\text { travelled } \\
(\text { miles } / 24 \mathrm{~h})\end{array}$} \\
\hline & & & & & & & \\
\hline \multicolumn{8}{|c|}{ I lb. pemmican } \\
\hline May 1954 & 9 & I8 & $9 \pi$ & 0.47 & -9 & 100 & 5.7 \\
\hline August r954 & 9 & 21 & 95 & 0.71 & -8 & 250 & 10.8 \\
\hline October I954† & 9 & I6 & 93 & 0.67 & +26 & 170 & II $\cdot 9$ \\
\hline March 1955 & I & $3 I$ & 77 & 0.29 & +23 & o & 0 \\
\hline April I955 & 9 & 7 & 89 & 0.45 & +12 & 20 & $1 \cdot 3$ \\
\hline August I955 & 9 & 8 & 88 & 0.93 & $-x 7$ & 190 & $9 \cdot 2$ \\
\hline November 1955 & I & 31 & $9 \mathrm{I}$ & 0.31 & +26 & o & $\circ$ \\
\hline \multicolumn{8}{|c|}{ I $\frac{1}{4} \mathrm{lb}$. pemmican } \\
\hline September $1955 \S$ & 9 & 24 & 82 & 0.16 & +13 & I ro & $6 \cdot 8$ \\
\hline September 1955 & 9 & 7 & $8 \circ$ & 0.26 & $+1 I$ & 250 & I I 4 \\
\hline September r 955 & 9 & 6 & 78 & 0.38 & + 10 & 270 & $16 \cdot 3$ \\
\hline $\begin{array}{l}\text { September to } \\
\text { October I955 }\end{array}$ & 9 & I5 & 75 & 0.11 & +10 & 130 & $9 \cdot 4$ \\
\hline October 1955 & 9 & 8 & 73 & 0.31 & +23 & IIO & $11 \cdot 2$ \\
\hline November 1955 & $\mathbf{I}$ & $3 I$ & 104 & 0.08 & +26 & 0 & 0 \\
\hline
\end{tabular}

Thiamine metabolism. In one dog, 7 years old, given $\mathrm{I}$ lb. pemmican a day and kept unworked, there was a gradual increase of bisulphite-binding substances in the urine. The concentration was originally equivalent to $18 \mathrm{mg}$ pyruvic acid/100 $\mathrm{ml}$., and in 30 days it gradually rose to $64 \mathrm{mg} / 100 \mathrm{ml}$. On the $35^{\text {th }}$ day $100 \mathrm{mg}$ thiamine were injected intramuscularly into the rectus femoris and $23 \mathrm{~h}$ later the urine was collected. The concentration of bisulphite-binding substances had dropped considerably and was equivalent to $34 \mathrm{mg}$ pyruvic acid/100 $\mathrm{ml}$. The results are not conclusive, but suggest that I lb. dog pemmican $/ 24 \mathrm{~h}$ at $24^{\circ} \mathrm{F}$ provided insufficient thiamine. It is realized that the analytical method used gives results that may not be precise.

Ascorbic-acid metabolism. All the urine examined contained large quantities of ascorbic acid. The amount excreted in $24 \mathrm{~h}$ by a dog at base on a diet of seal meat was about $100 \mathrm{mg} / 55^{\circ} \mathrm{ml}$. urine. The amount was slightly less on the pemmican diet, but even after 59 days' travel the mean daily excretion by the four dogs examined was $50 \mathrm{mg}$ or more. Two of the four dogs were in the worst physical condition of any in 
the group, and had marked palatal ulcers. Dog pemmican contains negligible quantities of ascorbic acid (Table I) and most of the $50 \mathrm{mg}$ excreted represents ascorbic acid synthesized in the body. There was, therefore, no evidence that sledge dogs need a dietary supply of ascorbic acid.

Gastric emptying time. An experiment was made to ascertain how long the pemmican diet, given in fairly large pieces, would remain in the stomach before passing to the intestine. Six surplus dogs were given I lb. pemmican; they were killed at intervals afterwards, and the quantity of diet remaining in the stomach was weighed. The results (Table 4 ) show that the stomach was empty between 14 and $\mathrm{I} 8 \mathrm{~h}$ later.

$\begin{gathered}\text { Table 4. Time required for I lb. pemmican to leave the stomach } \\ \text { in sledge dogs }\end{gathered}$
$\begin{array}{ccc}\text { Time since } & \begin{array}{c}\text { Estimated proportion } \\ \text { of pemmican left } \\ \text { in stomach (\%) }\end{array} \\ \text { Dog } & \text { feeding (h) } & 80 \\ \text { A } & 8 & 20 \\ \text { B } & 15 & 20 \\ \text { C } & 15 & 0 \\ \text { D } & 15 & 0 \\ \text { E } & 18 & 0 \\ \text { F } & 24 & \end{array}$

Faeces. Masterton, Lewis \& Widdowson (1955, 1957) have recorded that sledge dogs are liable to diarrhoea and have the habit of eating their own or human faeces. The faeces of normal sledge dogs are dark and fairly liquid. Faeces from dogs on the whale diet were sometimes orange in colour, in contrast to the black and brown of those receiving beef pemmican. After from 10 to 20 days on a diet of pemmican the dogs began to smell at and then to eat their own and other dogs' faeces, and the colder the temperature, the sooner they did so, but a team of dogs was never recorded as eating more than one-third of its total faecal output. The results of analysis of the faeces are summarized in Table 5 .

Water balance. Normally the dogs ate snow; they rarely had the chance to drink.

Table 5. Mean values for dry matter, nitrogen and fat in the diet and in the faeces of sledge dogs

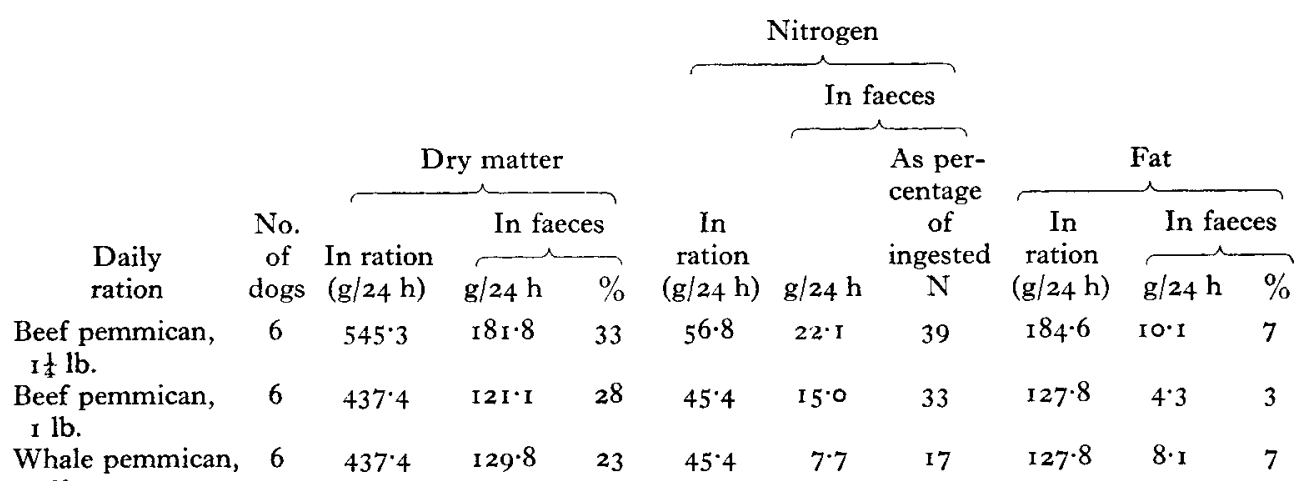

I lb. 
It is a good measure of their adaptation to the cold that they could eat snow at $-50^{\circ} \mathrm{F}$ $\left(-45^{\circ} \mathrm{C}\right)$. An attempt was made to estimate the intake and output of water in $24 \mathrm{~h}$ by a $\operatorname{dog}$ at $24^{\circ} \mathrm{F}\left(-4^{\circ} \mathrm{C}\right)$ on $\mathrm{Ilb}$. pemmican. The intake of water from snow was approximately $1000 \mathrm{~g}$, and that present in the food $20 \mathrm{~g}$. The measured total urinary output was $55^{\circ} \mathrm{ml}$. and the faeces contained approximately $500 \mathrm{~g}$ water. The output of water in the urine and faeces was thus considerable and there was need for a large intake which, since it was in the form of snow, demanded some roo Cal./24 $\mathrm{h}$ to melt it.

Work performance. Nine dogs were used to pull each sledge. A fully laden sledge weighed I $100 \mathrm{lb}$. and the pull needed to move it varied from $50 \mathrm{lb}$. on ice to $300 \mathrm{lb}$. or more on soft snow. On reasonable surfaces the speed of the dogs was between 3 and 5 m.p.h., but on account of weather most journeys averaged only about 10 miles in $24 \mathrm{~h}$. The work output has been described elsewhere (Taylor, $1957 \mathrm{~b}$ ).

\section{Laboratory work in Britain}

The results obtained from three series of tests with the husky dog, Dusty, in a metabolism cage are set out in Table 6. Continuous records were taken of environmental temperature within the metabolism cage, and it was never outside the range of $58-68^{\circ} \mathrm{F}$.

In the first series with the standard diet I the results obtained with Dusty were similar to those for the other experimental animals, which shows there were no special breed differences. When this dog was received from Greenland he had the loose stools usual in huskies; after a period on the standard diet I the faeces became firmer and better formed and like those of the other dogs.

In the second series, still with the standard diet $\mathrm{I}$, the effect of an addition of synthetic thiamine was investigated. Doses of the vitamin, similar to those used in earlier studies (Worden, Waterhouse \& Partington, 1955), were given, and the effect on urinary excretion of thiamine was measured. It was found that, even with the largest dose, only a small fraction of it appeared in the urine on the following days, as in our earlier studies. The amounts of other urinary constituents were measured at the same time. The vitamin A excretion on the standard diet was like that previously reported (Worden, Bunyan, Davies \& Waterhouse, 1955), the values obtained on three separate dates being 36,59 and 17 i.u. $/ 24 \mathrm{~h}$. The output of ascorbic acid on two separate occasions was 400 and $85 \mathrm{mg} / 24 \mathrm{~h}$.

In a third series of tests, the unmodified pemmican diet 4 was used and significant differences were found when the urine was analysed. In spite of the fact that the dog drank from 920 up to as much as $2000 \mathrm{ml}$. water each day, there was a considerable decrease in the volume of urine, accompanied, as might be expected, by an increase in the specific gravity. The urine in experiments with the standard diet was usually alkaline, $\mathrm{pH} 8 \cdot 0-8 \cdot 5$; with the pemmican diet it was invariably acid, $\mathrm{pH} 6 \cdot 0-6 \cdot 7$. No results for excretion of thiamine or riboflavin are given as with the standard diets. The omission is due to a change in the character of the urine when the dog was on the unmodified pemmican diet. Substances then appeared in the urine which caused such a degree of interference with the fluorimetric determinations that the results were vitiated. In estimating riboflavin the blank determination was extremely high owing 


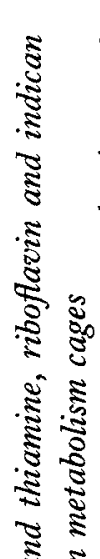

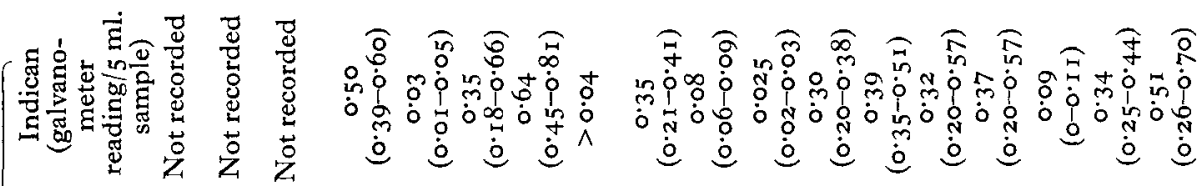

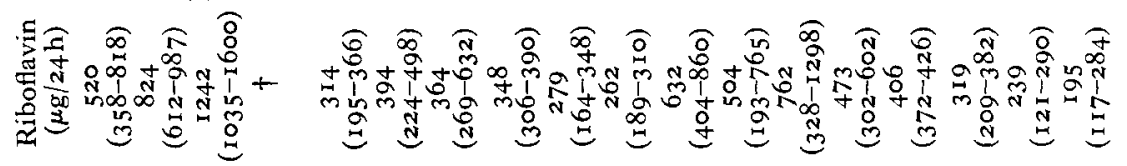

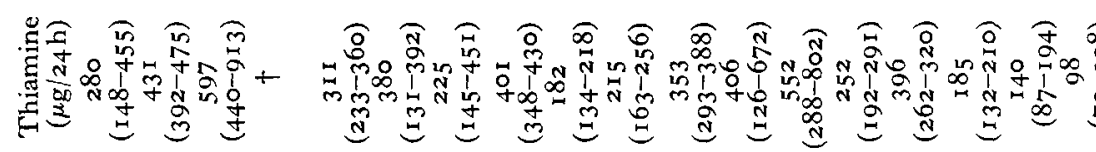

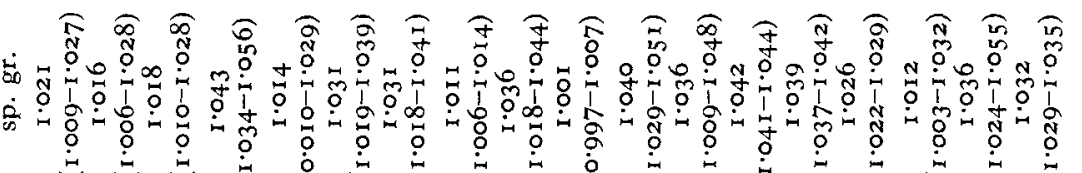

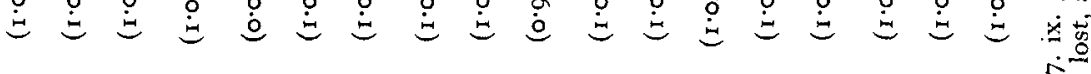

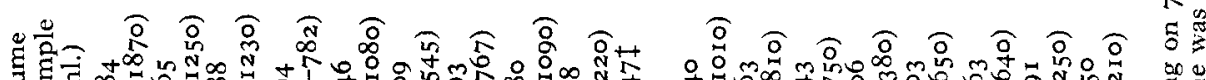

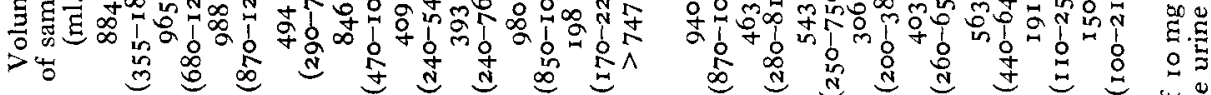

है.

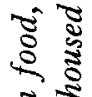

: 5

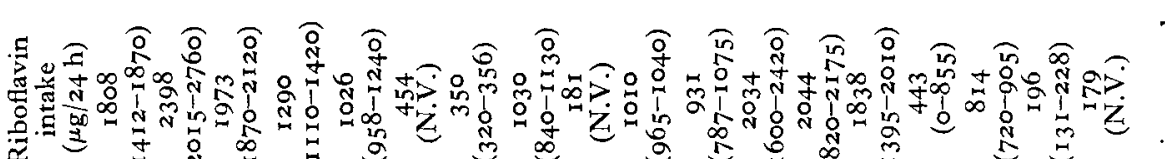

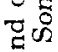

รั้

ㅊำ

-

ำ

路

:

ฐ

E

$\circ$

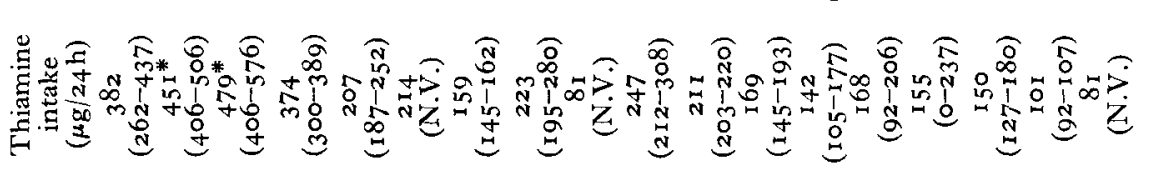

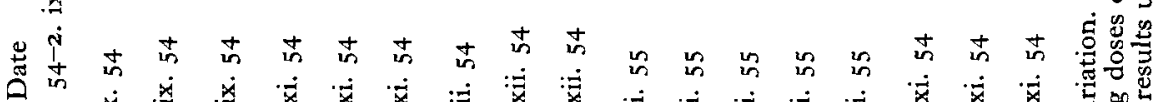

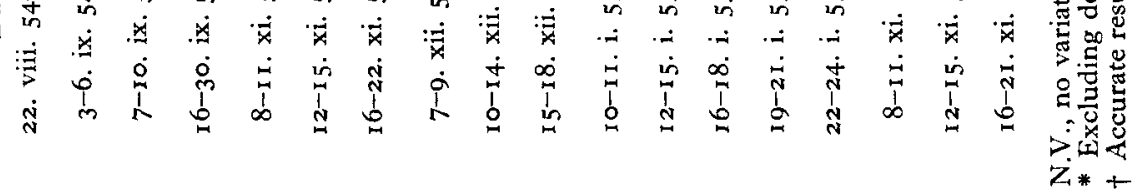

$\stackrel{20}{\circ}$

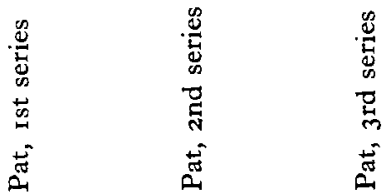

兽 
to the presence of extraneous fluorescent material, and at the oxidation stage the amount of permanganate required was excessive. In the determination of thiamine a substantial proportion of fluorescent material was present which was not thiochrome. The vitamin A excretion on the pemmican diet was greater, the values recorded on four occasions being $215,144,67$ and 142 i.u. $/ 24 \mathrm{~h}$, but was not unlike the excretion recorded in adult dogs in an earlier paper (Worden, Bunyan, Davies \& Waterhouse, 1955). The ascorbic-acid values recorded were 241,620 and $487 \mathrm{mg} / 24 \mathrm{~h}$. The presence of substances interfering with the vitamin tests led to the suspicion that significant amounts of indigoid pigments might be present, so determinations of indigoid pigments measured as indican were carried out; the figures in Table 6 show the presence of substantial quantities in all the samples examined.

After the husky dog, Dusty, had returned to the Antarctic, similar experiments were made with our own animals to discover possible breed differences, and to ascertain the effect of dietary changes. The results of three series of tests on the dog Pat in the metabolism cage are included in Table 6. The environmental temperature in the metabolism cage was within the same range as for the husky.

The transition from the unmodified standard diet $\mathrm{I}$ to the unmodified pemmican diet 4 caused a marked reduction in the output of urine, which occurred although water consumption was unrestricted; the dog drank daily from 430 to $820 \mathrm{ml}$. water. There was again a marked increase in the urine of indigoid pigments when pemmican diets 4 and 5 were given. With the dog Pat the $\mathrm{pH}$ of the urine, being always on the acid side, showed less change; on standard diet $\mathrm{I}$ the $\mathrm{pH}$ was from $6 \cdot 1$ to 7.0 and on pemmican diets 4 and 5 from 5.8 to 6.7 . The amount of substances interfering with the thiamine test was less in the urine of Pat than of Dusty, but the values are, nevertheless, probably on the high side.

In a second series of tests with the dog Pat, the volume of urine voided per $24 \mathrm{~h}$ decreased considerably as soon as the dog was given the modified pemmican diet 6 , and rapidly returned to the normal amount when the diet was changed back to standard diet I towards the end of the experiment. The drop in urine volume to only onequarter of the normal was particularly striking since the water intake was unrestricted. The tendency to abstain from water while on the dehydrated diets was noted in Pat on more than one occasion. In fact, on one day, the ist day on modified pemmican diet 6 , the dog completely refused to drink water and on the 4 further days the voluntary intake ranged from 140 to $450 \mathrm{ml} / 24 \mathrm{~h}$; on the standard diet $\mathrm{I}$ he had been taking $750 \mathrm{ml}$. water $/ 24 \mathrm{~h}$. The specific gravity of the urine and its content of indigoid pigments, measured as indican, increased while pemmican diet 6 was being given.

In a third series with the same dog, modifications of the standard diet were given, and there was some difficulty in getting Pat to eat the food. It was necessary to include much rabbit flesh in modifications 2 and 3 of the standard diet to make them equivalent in protein content to the pemmican diet 4 , also in the modification 3 there was much glucose. The dog co-operated to the best of his ability, but it was obvious that he did not want so much food under the conditions of life in a metabolism cage; he would only eat the whole of it when coaxed. In spite of eating so much food, Pat 
lost $2 \mathrm{~kg}$ weight in $I_{5}$ days. While receiving pemmican diets 4 and 6 , Pat had loose stools, though not as markedly as Dusty.

The results of tests in the metabolism cage with the third dog, Scottie, are included in Table 6; they are similar to those for Dusty and Pat.

In addition to the results presented in Table 6, the excretion of inorganic phosphate, urea, creatinine and creatine was recorded throughout for all three dogs. The results will be presented in a later communication.

\section{DISCUSSION}

The nutritional requirements of sledge dogs, in so far as they are known, are similar to those of other breeds of dog. For example, there is published evidence that the daily requirement for thiamine of a dog of $90 \mathrm{lb}$. (4I kg) body-weight is about $0.7 \mathrm{mg}$ (Michaud \& Elvehjem, I943-4; Krehl, I947). The pemmican diet contains in each I lb. ration about $0.4 \mathrm{mg}$ thiamine, and that amount appeared to be insufficient.

Claims have been made that large therapeutic doses of ascorbic acid are of advantage to dogs (Garlick, I946) but it is clear that in European temperate climates dogs can synthesize a sufficiency of ascorbic acid and do not suffer from scurvy (Innes, I93 I). In cold climates and with hard work the ascorbic-acid requirement increases, and it has been suggested that sledge dogs might develop scurvy. No evidence to support this suggestion was obtained and the development of palatal ulcers by sledge dogs must be attributed to some other cause. The observation again illustrates the similarity between the nutritional requirements of the husky and of other breeds of dog.

Certain events occurred in the Antarctic that were not foreseen. On the normal daily ration of $\mathrm{I} \mathrm{lb}$. pemmican the dogs lost weight even when not working. For man on sledging rations, Fuchs (1952) found that the ratio of dry matter excreted to that ingested was about $\mathrm{I}: 33$. Most of the faeces on this same expedition had a high total fat content (mean $82 \%$ on a dry-weight basis) with reversal of the normal proportion of split to unsplit fat (Butson, 1950). Masterton et al. (1957) recorded only $23 \%$ total fat in faeces of men on the British North Greenland Expedition. With our sledge dogs, in contrast, the dry matter in the faeces was mostly protein, faecal fat not exceeding $7 \%$ on a dry-matter basis, and the ratio of dry matter excreted to that ingested was about $\mathrm{I}: 4$. With the dogs on pemmican the loss of nitrogen from the gut was about one-third of the intake, and the loss of fat in the faeces was about $6 \%$ of the intake. The loss for men on sledging rations has been found to be $7 \%$ (Butson, I950; Masterton et al. 1955). The utilization of fat by the dogs was, therefore, reasonably good, which may have been due to the long time, about ${ }_{5} \mathrm{~h}$, during which pemmican has been found to remain in the stomach.

Masterton et al. (1955) and Lewis, Masterton \& Ward (1957) state that husky dogs accompanying the British North Greenland Expedition had a ravenous appetite but became tired of pemmican. When offered a prepared dog-food, they would take it only as a last resort, but they stole biltong and ate it with avidity. Lewis et al. (1957) suggested that a form of biltong prepared from horseflesh or similar cheap meat might be introduced advantageously into the dog ration.

The laboratory studies here reported support the observations in the field and show 
that a diet of pemmican alone is unbalanced and productive of biochemical and clinical changes even in dogs in metabolism cages in a temperate climate. Cuthbertson \& Munro (r939) showed that, when the carbohydrate and protein portions of an otherwise adequate diet were given separately, the nitrogen balance was negative. There is evidence from the Antarctic that a single feed of fresh seal meat will re-invigorate a team of dogs that is tending to fail on a diet of pemmican alone, but it would seem a more satisfactory solution to improve the composition of the diet provided. Sir Vivian Fuchs (personal communication) has described the feeling of benefit derived by himself and his colleagues from the daily consumption of a small quantity of biscuit in addition to a basal diet consisting mainly of protein and fat. Hobson (I939) showed that men on low-carbohydrate diets had a disinclination for muscular work and were quickly fatigued. Both endogenous and exogenous protein metabolism are affected by substituting fat for carbohydrate in the ration, but the effect on the exogenous metabolism is much the more pronounced and, according to Cuthbertson \& Munro (1939), would then depend on the carbohydrate's being given with the dietary protein (Thomson \& Munro, 1955).

There has been considerable controversy, particularly in veterinary and agricultural literature, about the existence of 'protein poisoning'. The experiments of Newburgh (I9I9), who produced albuminuria and renal damage in rabbits by giving them hardboiled egg white, may have been complicated by other factors. There is, nevertheless, ample evidence that nitrogen is wasted by man, the dog and other species of animal through restriction of caloric intake or through relative excess of dietary protein (Benditt, Humphreys, Wissler, Steffee, Frazier \& Cannon, 1948; Rosenthal, 1952; Spector \& Calloway, 1953; and many others). In pemmican, as given to dogs, there would certainly appear to be an excess of protein as evidenced by the marked faecal loss and by the development of indicanuria.

Indican is not a normal urinary constituent of adult man or dogs, and Moustafa el-Hehyawi (I955), working in hot weather in Cairo, showed that the urine was indicanfree in about $70 \%$ of dogs, and in the remainder the amount ranged up to $0.47 \mathrm{mg}$ / I00 $\mathrm{ml}$. Rimington (1946) studied the urinary excretion of an indigoid pigment in a patient suffering from sprue. The quantity of pigment increased greatly when the patient received a diet high in protein but normal in fat, and on this diet his condition deteriorated; the results resemble those in our dogs confined in metabolism cages, and are consistent with the finding that bodily condition deteriorates after some weeks in the field on such diets.

The appearance of fluorescent pigments in the urine of dogs receiving pemmican may have been due in part to interference with vitamin metabolism. Najjar, Stein, Holt \& Kabler ( 1942 ) found that dogs suffering from black-tongue excreted a fluorescent pigment which they designated $F_{1}$, and that when nicotinic acid was administered a second fluorescent substance, $F_{2}$, was excreted in its place. Raoul (I943) reported that the urine of patients suffering from pellagra and treated with nicotinamide contained derivatives of indoxyl and indole considered to be responsible for the blue fluorescence encountered.

Mendel \& Fine (I9I2), experimenting on dogs, showed that the utilization of 
nitrogen from meat was less when the meat was given as powder than as fresh meat. The amount of nitrogen in the faeces was greater with the powder. Prausnitz (I9OI) showed that dried meat had a lower coefficient of digestibility than fresh meat, with a higher percentage of nitrogen in the faeces. Dried meat was less well digested by artificial gastric juice. Such effects may well have been due, at least in part, to the injurious effect of processing on the availability of one or more essential amino acids. Morgan \& Kern (1934) showed that heat treatment lowered the biological value of meat protein for dogs. Harms \& Scott (1956) demonstrated the adverse effect of drying a stock diet for dogs at temperatures above $140^{\circ} \mathrm{F}$. The food became more resistant to peptic digestion. In that and other studies indicating loss of protein value during processing (Bissett \& Tarr, I954) there was no evidence, from the analysis of hydrolysed samples, that essential amino acids are destroyed. Lysine may become bound, through the $\epsilon$-amino group, to reducing sugars or to other materials within the intact protein, and thus become unavailable (Carpenter \& Ellinger, 1955). There would seem to be ample opportunity for such binding to occur during the manufacture of pemmican.

Our dogs receiving pemmican showed no oedema or gain in weight, despite retention of water. The volume of urine excreted by Dusty on a pemmican diet in a metabolism cage was very similar to those recorded in the field. Any assessment of water balance must take into consideration the somewhat specialized drinking pattern which dogs adopt. Towbin (1955) has shown that the dog favours a characteristic size of drink not markedly affected by the total intake of water or food. At higher environmental temperatures dogs take larger amounts of water by drinking the same volume more frequently.

Although the development of fluorescent urinary pigments interfered with tests for thiamine and riboflavin, there seems little doubt that consumption of pemmican was accompanied by decrease in the urinary excretion of both vitamins, especially thiamine. The finding is in keeping with our previous observations that dogs in the Antarctic excreted more bisulphite-binding substances. Banerji (194I) found that large amounts of protein in the diet prevented signs of thiamine deficiency in rats; there was no bradycardia and no loss of weight, but there was increased excretion of bisulphitebinding substances. Fat, on the other hand, prevented the increase and relieved the other effects of thiamine deficiency.

Arnrich, Hurley, Forker \& Morgan (1956) showed that, in young dogs receiving diets deficient in riboflavin or pantothenic acid, forced exercise led to collapse in hypoglycaemic coma. Those deprived of pantothenic acid could be revived by administration of adrenal cortical extract, but those deprived of riboflavin could not. Since the riboflavin intake on pemmican diet is known to be low, it may be that cases of collapse reported in the past in working huskies after periods of Ioo days or more on pemmican diet could be due to that cause.

\section{Development of an improved sledging diet}

There was pressing need for an improved diet for dogs for various purposes, including the dogs of the Trans-Antarctic Expedition of $1957-8$, so a ration was designed 
which would conform to the demands of sledging and be better balanced than pemmican. After some experiment, the required physical characteristics were achieved and a diet was designed. Its percentage composition is:

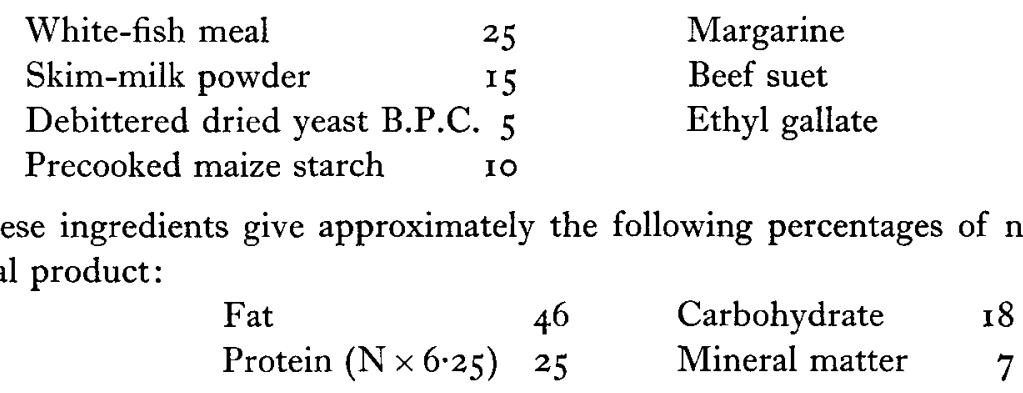

Each I lb. block has theoretically a caloric value of $2800 \mathrm{Cal}$. and contains the following added vitamins:

$\begin{array}{lrll}\text { Vitamin A (i.u.) } & \text { 1000 } & \text { Riboflavin (mg) } & 3 \cdot 0 \\ \text { Vitamin D (i.u.) } & 600 & \text { Calcium pantothenate (mg) } & 2 \cdot 0 \\ \text { Thiamine (mg) } & \mathrm{I} \cdot 2 & \text { Pyridoxine (mg) } & 0 \cdot 4 \\ \text { Nicotinic acid (mg) } & 9 \cdot 0 & & \end{array}$

Preliminary metabolism tests and trials of palatability showed that it is an acceptable diet which does not lead to urinary abnormalities. The results of a detailed investigation of its metabolic effects when used in Great Britain and in Grahamland will be published in due course, together with a report on its practical use as a sledging ration.

From Grahamland we have just heard that the preliminary results of the trials are encouraging. The new diet is more completely digested than dog pemmican, and is more successful in maintaining body-weight.

\section{SUMMARY}

I. The results are presented of a study conducted jointly in the Antarctic and in England.

2. Evidence was collected in the Antarctic of the sledging diet for dogs in use over the past 26 years. It was found to consist on journeys of a daily allowance for each animal of a I lb. $(0.454 \mathrm{~kg})$ block of dog pemmican, a dried and concentrated food made mainly from beef and consisting of about two-thirds protein and one-third fat. Occasionally other rations have been given.

3. Dogs receiving a daily allowance of $0.454 \mathrm{~kg}$ of the pemmican as their sole food lost weight even when not working, in contrast to those at base receiving 6-8 $\mathrm{lb}$. $(2 \cdot 7-3 \cdot 6 \mathrm{~kg})$ of seal meat on alternate days. Practical experience over $\mathrm{I} 2$ years had indicated the adequacy of the diet given at base.

4. Surplus dogs that had received single feeds of $0.454 \mathrm{~kg}$ of the pemmican were killed at intervals to determine the time of disappearance of food from the stomach. It was found that complete emptying had occurred within $14-18 \mathrm{~h}$.

5. The analysis in England of samples of faeces collected from dogs fed on pemmi- 
can in the Antarctic showed that about one-third of the intake of nitrogen and about $6 \%$ of the fat were excreted in the faeces.

6. Dog pemmican analysed in England was found to contain only small quantities of thiamine and ascorbic acid, and to be without any detectable vitamin A.

7. In England one husky and two other dogs were housed in metabolism cages and fed on pemmican and other diets in which the ratio of protein to carbohydrate was varied. Urine samples were collected and analysed.

8. During pemmican feeding there were abnormal urinary changes, retention of water, indicanuria, and excretion of fluorescent substances. There was reduction in the output of thiamine and of riboflavin. The animals themselves sometimes lost weight and tended to develop loose stools.

9. It is concluded that pemmican is an ill-balanced diet, with an abnormal and wasteful ratio of protein to carbohydrate, which, together with damage during manufacture, accounts for the unsatisfactory results in the field.

10. A diet believed to be more suitable for use in the field has been devised and is in use.

The authors wish to thank in particular Sir Vivian Fuchs and Dr G. C. L. Bertram who made the field investigation possible; Professor R. A. McCance, F.R.S., Dr Elsie M. Widdowson and the staff of the Department of Experimental Medicine, Cambridge, where much advice was given and the faeces were analysed; Major W. E. Anderson, M.B.E., M.C., Dr P. M. O. Massey and Dr N. A. G. Leppard and many others at Hope Bay; Professor Sir James Gray, F.R.S.; Professor C. Rimington, F.R.S., of University College Hospital Medical School, for his advice and guidance concerning indigoid pigments; the Royal Society who supported the programme in the field with a grant; and also our colleagues Miss M. Hardaker, Miss B. P. Wells, Mr J. Bunyan, Mr H. Partington, Mr R. N. Pulman and Mr M. Rix for making the analytical determinations and for the care of the experimental animals.

Footnote added 7 August 1958 . Since this paper was prepared we have received confirmation from the Trans-Antarctic Expedition that the new diet and dog pemmican were given to all dogs on alternate days during a $25^{\circ}$-mile traverse in the Shackleton Mountains and during the journey of $57^{\circ}$ miles between South Ice and the South Pole. The huskies had diarrhoea after each feed of pemmican, but not after the new diet on which, in the opinion of their drivers, they did far better. The analyses of samples of faeces in digestibility trials carried out under Antarctic conditions, with an intake of either diet of $454 \mathrm{~g} / 24 \mathrm{~h}$, showed mean faecal outputs $(\mathrm{g} / 24 \mathrm{~h})$ as follows:

$\begin{array}{lcccc} & \text { Moisture } & \text { Dry } & & \\ \text { matter } & \text { Nitrogen } & \text { Fat } \\ \text { New diet } & 266 & 49 & 1 \cdot 8 & 7 \cdot 5 \\ \text { Pemmican } & 533 & 66 & 7 \cdot 3 & 3 \cdot 6\end{array}$

Faeces excreted on the new diet contained $4.2 \%$ nitrogen and $14.6 \%$ fat, compared with $\mathrm{I} . \cdot 0 \%$ nitrogen and $5.5 \%$ fat on pemmican. We are indebted to $\mathrm{Dr} \mathrm{H}$. T. Wyatt for these results. 


\section{REFERENCES}

Adie, R. J. (1953). Polar Rec. 6, 63 I.

Arnrich, L., Hur'ey, L. S., Forker, B. R. \& Morgan, A. F. (1956). Amer. F. Physiol. 184, 5 15.

Association of Official Agricultural Chemists (1955). Official Methods of Analysis, 8th ed. Washington, D.C.: Association of Official Agricultural Chemists.

Banerji, G. G. (1941). Biochem. F. 35, 1354.

Banerji, G. G. \& Harris, L. J. (1939). Biochem. F. 33, 1346.

Benditt, E. P., Humphreys, E. M., Wissler, R. W., Steffee, C. H., Frazier, L. E. \& Cannon, P. R. (1948) F. Lab. clin. Med. 33, 257.

Bessey, O. A. (1938). F. biol. Chem. 126, 77 I.

Bissett, H. M. \& Tarr, H. L. A. (1954). Poult. Sci. 33, 250.

Butson, A. R. C. (1950). Lancet, 258, 993.

Carpenter, K. J. \& Ellinger, G. M. (I955). Poult. Sci. 34, 145 I.

Cuthbertson, D. P. \& Munro, H. N. (1939). Biochem. $\mathcal{F} .33,128$.

Falkland Islands Dependencies Survey (1954). Polar Rec. 7, 166.

Falkland Islands Dependencies Survey (1956). Polar Rec. 8, 260.

Fuchs, V. E. (1951). Polar Rec. 6, 7.

Fuchs, V. E. (1952). Polar Rec. 6, 508.

Garlick, N. L. (1946). F. Amer. vet. med. Ass. 109, 70.

Godden, W. (1937). Tech. Commun. Bur. Anim. Nutr., Aberd., no. 9.

Harms, A. J. \& Scott, P. P. (1956). Y. Sci. Fd Agric. 7, 477.

Harris, L. J. \& Ray, S. N. (1935). Lancet, 228, 7 I.

Harris, L. J. \& Wang, Y. L. (1941). Biochem. F. 35, 1050.

Hobson, W. (1939). Biochem. F. 33, 1425.

Innes, J. R. M. (1931). Rep. Inst. Anim. Path. Univ. Camb. p. 143.

Jowett, M. (1940). Biochem. F. 34, I 348 .

King, E. J. (195I). Micro-analysis in Medical Biochemistry, and ed. London: J. and A. Churchill Ltd.

Kodicek, E. (1940). Biochem. F. 34, 712.

Kodicek, E. \& Wang, Y. L. (1949). Biochem. F. 44, 340.

Krehl, W. A. (1947). F. Amer. vet. med. Ass. 110, 12 I.

Lawrie, N. R., Moore, 'T. \& Rajagopal, K. R. (194I). Biochem. F. 35, 825.

Lewis, H. E., Masterton, J. P. \& Ward, P. G. (1957). Brit. F. Nutr. II, 5.

Lindsay, M. (I935). Sledge. London: Cassell and Co. Ltd.

McCance, R. A. (195I). In Spec. Rep. Ser. med. Res. Coun., Lond., no. 275, p. 2 I.

Mason, D. P. (1950). Geogr. F. I15, I45.

Masterton, J. P., Lewis, H. E. \& Widdowson, E. M. (1955). Proc. Nutr. Soc. 14, xvi.

Masterton, J. P., Lewis, H. E. \& Widdowson, E. M. (1957). Brit. F. Nutr. 11, 346.

Mendel, L. B. \& Fine, M. F. (1912). F. biol. Chem. xI, 5.

Michaud, L. \& Elvehjem, C. A. (1943-4). Nutr. Abstr. Rev. 13, 323.

Morgan, A. F. \& Kern, G. E. (1934). F. Nutr. 7, 367.

Moustafa el-Hehyawi, G. E. (1955). Brit. vet. $\mathcal{~}$. III, 73.

Najjar, V. A., Stein, H. J., Holt, L. E. Jr. \& Kabler, C. V. (I942). F. clin. Invest. 2I, 26.

Newburgh, L. H. (1919). Arch. intern. Med. 24, 359.

Prausnitz, K. (1901). Z. Biol. 42, 377.

Raoul, Y. (1943). Bull. Soc. Chim. biol., Paris, 25, 266.

Rimington, C. (1946). Biochem. F. 40, 669 .

Rosenthal, H. L. (1952). F. Nutr. 48, 243.

Spector, H. \& Calloway, D. H. (1953). Fed. Proc. 12, 430.

Taylor, R. J. F. (1957a). Polar Rec. 8, 317.

Taylor, R. J. F. (1957b). F. Physiol. 137, 210.

Taylor, R. J. F. (1957c). Polar Rec. 8, 429.

Thomson, S. W. T. \& Munro, H. N. (1955). \%. Nutr. 56, 139.

Towbin, E. J. (1955). Amer. F. Physiol. 182, 377.

Voit, M. (1904). Z. Biol. 45, 79.

Watkins, H. G. (1932). Geogr. F. 79, 466.

Winton, A. L. \& Winton, K. B. (1945). The Analysis of Food. London: Chapman and Hall.

Worden, A. N., Bunyan, J., Davies, A. W. \& Waterhouse, C. E. (1955). Biochem. F. 59, 527.

Worden, A. N. \& Waterhouse, C. E. (1955). Brit. F. Nutr. 9, 5.

Worden, A. N. \& Waterhouse, C. E. (1956). F. Anim. Tech. Ass. 7, 47.

Worden, A. N. Waterhouse, C. E. \& Partington, H. (1952). Vet. Rec. 64,836 .

Worden, A. N., Waterhouse, C. E. \& Partington, H. (1954). Vet. Rec. 66, 169.

Worden, A. N., Waterhouse, C. E. \& Partington, H. (1955). Vet. Rec. 67, 503.

Worden, A. N., Waterhouse, C. E. \& Pulman, R. N. (1956). Vet. Rec. 68, I47. 